\title{
Quality transformation of dissolved organic carbon during water transit through lakes: contrasting controls by photochemical and biological processes
}

5 Martin Berggren ${ }^{1}$, Marcus Klaus ${ }^{2}$, Balathandayuthabani Panneer Selvam ${ }^{1}$, Lena Ström ${ }^{1}$, Hjalmar Laudon $^{3}$, Mats Jansson ${ }^{2}$, Jan Karlsson ${ }^{2}$

${ }^{1}$ Department of Physical Geography and Ecosystem Science, Lund University, SE-223 62, Lund, Sweden

${ }^{2}$ Department of Ecology and Environmental Science, Umeå University, SE-90187, Umeå, Sweden 10

${ }^{3}$ Department of Forest Ecology and Management, Swedish University of Agricultural Sciences, SE-90183, Umeå, Sweden

\section{Summary of SI Contents:}

Text S1. Supplemental methods

Figure S1. Means $\pm 1 S D$ of hydrological variables describing lake mixing, catchment discharge and water transit time as functions of time of year

Figure S2. Timeline plots for the absorbance ratio a254 : a365 and the measured total concentration of low molecular weight carbon compounds

Figure S3. Losses in dissolved organic carbon and in color during 2-week dark bioassays in $20^{\circ} \mathrm{C}$ 


\section{Text S1. Supplemental methods}

\section{Discharge measurements}

Daily discharge for the whole study periods 2012-2014 was extracted from hourly measurements performed for five of the study lakes, either at the outlet or at the inlet. Inlet measurements were re-scaled through multiplication by the ratio of 'outlet catchment area' : 'inlet catchment area'. Water height loggers of model WT-HR 100 (Trutrack Inc., New Zealand) were placed at reaches with well-defined banks, and discharge was calculated using established rating curves based on the salt dilution method (number of observations per stream: 24-32, normalized root mean square error: 0.13-0.29). In the four lakes with the smallest catchments (Lapptjärn, Mångstrettjärn, Nästjärnen and Fisklösan), we considered inlet runoff to be too small to be assessed from water height. These lakes had no continuously flowing inlets and diffuse water flow may dominate during parts of the year. For these lakes, we assumed that specific discharge was identical to that of the lake Övre Björntjärnen, and thus we rescaled the discharge from Övre Björntjärnen according to the catchment size of each of these four lakes. The assumption of similar specific runoff can be justified by the proximity of the lakes (see Table S1), the similar catchment slope gradient (ca $10 \%$ ) and composition of bedrock (paleoproterozoic granitoids etc.), soils (peat and podzol soils on glacial till) and vegetation (coniferous forest and peatlands).

Prior to 2012, discharge for all sampled lakes was approximated from specific discharge from the stream Kallkällsbäcken in the Krycklan catchment (50 km northeast of Övre Björntjärnen), where stream water levels have been recorded continuously since 1980 using a pressure transducer and a $90^{\circ} \mathrm{V}$-notch weir housed in a heated shed (Laudon et al. 2013). Discharge measured at the Övre Björntjärnen inlet, 1996-1998 (Jansson et al. 2001), indicated that the mean specific discharge (approximately $10 \mathrm{~L} \mathrm{~s}-1 \mathrm{~km}-2$ ) was not significantly different from that recorded in the Krycklan catchment over the same period (Köhler et al. 2008). Moreover, manually registered water levels at the inlet of Övre Björntjärnen on a total of 18 dates, 2007-2009, demonstrated a strong correlation with the water level in the Krycklan stream $\left(R^{2}=0.85, n=18, p<\right.$ $0.01)$.

\section{References to supplemental methods Text S1}

Jansson, M., A. K. Bergström, S. Drakare, and P. Blomqvist. 2001. Nutrient limitation of bacterioplankton and phytoplankton in humic lakes in northern Sweden. Freshwat. Biol. 46: 653-666.

Köhler, S. J., I. Buffam, H. Laudon, and K. H. Bishop. 2008. Climate's control of intra-annual and interannual variability of total organic carbon concentration and flux in two contrasting boreal landscape elements. J. Geophys. Res. Biogeosciences 113: G03012.

Laudon, H., I. Taberman, A. Agren, M. Futter, M. Ottosson-Lofvenius, and K. Bishop. 2013. The Krycklan Catchment Study-A flagship infrastructure for hydrology, biogeochemistry, and climate research in the boreal landscape. Water Resour. Res. 49: 7154-7158. 

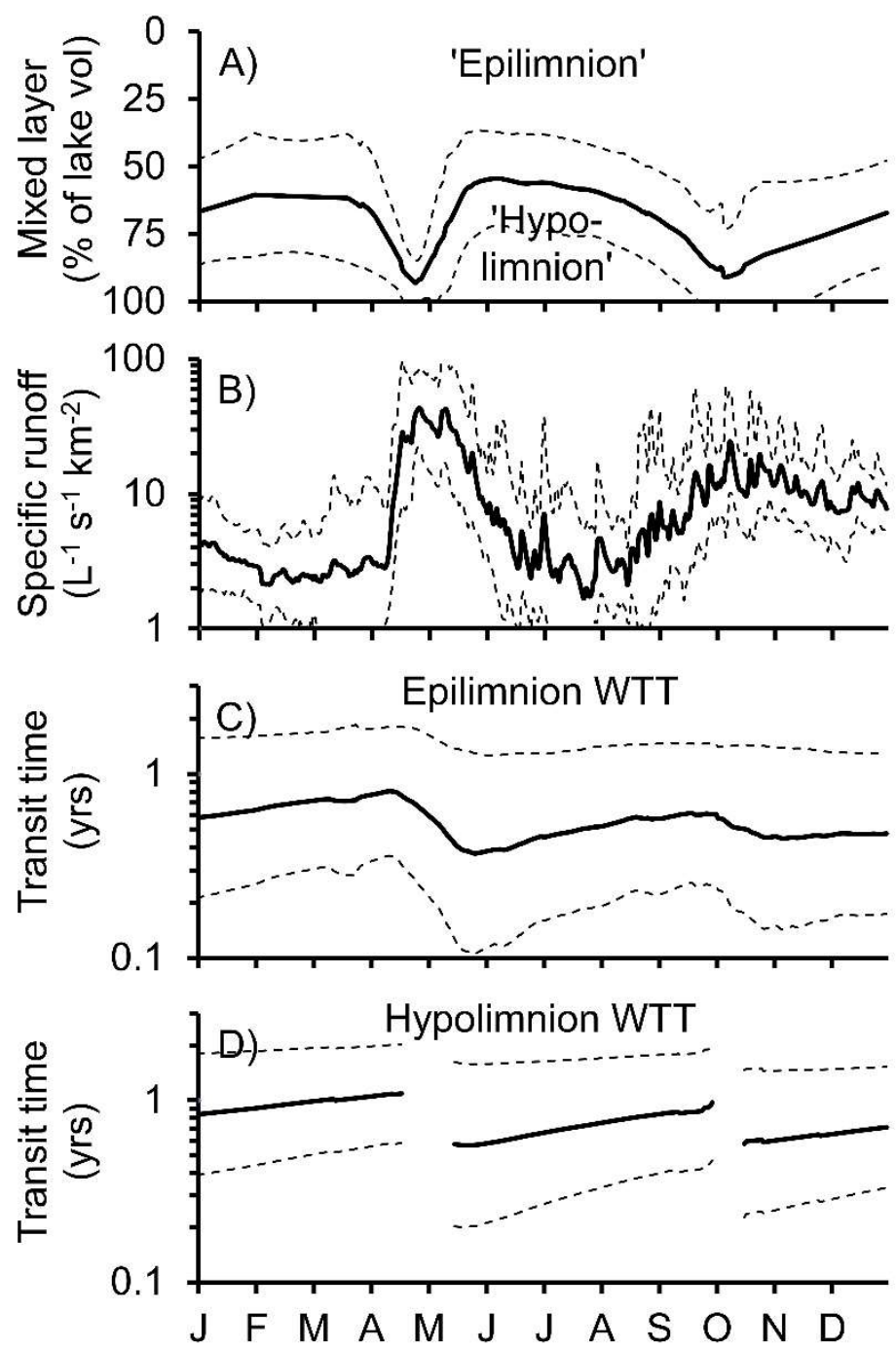

Figure S1. Means (solid lines) \pm 1 SD (dotted lines) of hydrological variables describing (A) lake mixing, (B) catchment discharge and (C-D) water transit time (WTT) as functions of time of year (month of year). Note that B-D show mean and $S D$ derived from the log-normal distribution of y-axis values. The variables were assessed separately for each lake and study year, but for illustrative purposes

5 the figure shows the average of 38 linearly interpolated curves obtained from 9 lakes in northern Sweden during 3-7 years of measurement per lake. The hypolimnetic WTT (in D) is only shown for periods during which the hypolimnion was typically present. 


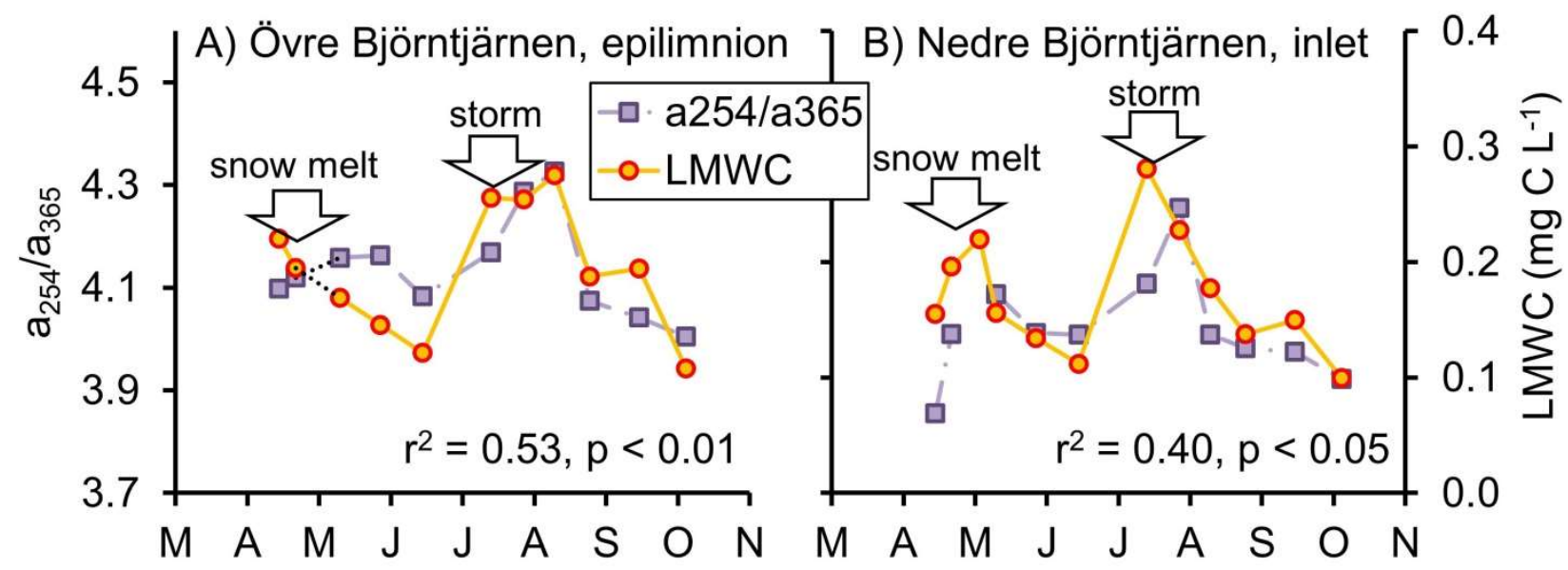

Figure S2. Timeline plots for the absorbance ratio $\mathbf{a}_{254}: \mathbf{a} 365$ and the measured total concentration of low molecular weight carbon compounds (LMWC), shown for two sites in the Björntjärnarna catchment (A and B, respectively) from April to October 2009. Significant correlations between the two variables are indicated by the statistics below each curve pair. The LMWC represents a sum of 39 of the most common organic acids, free amino acids and simple carbohydrates. 


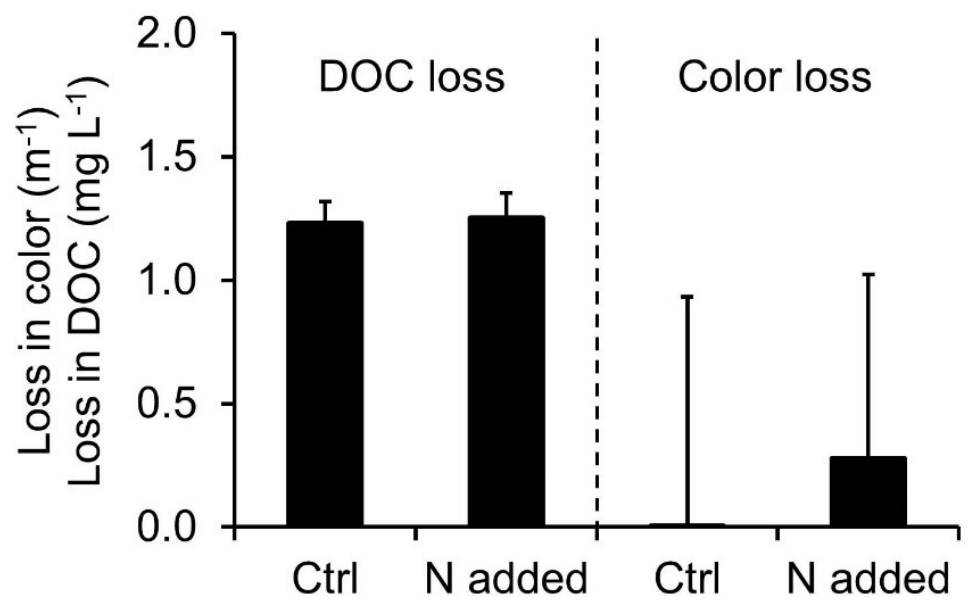

Figure S3. Losses in dissolved organic carbon (DOC) and in color (absorbance at $420 \mathrm{~nm}$ ) during 2-week dark bioassays in $20{ }^{\circ} \mathrm{C}$ performed on ambient and nitrogen-amended water from Nedre Björntjärnen (four replicate dates representing different seasons). If $\mathrm{N}$ was limiting the DOC processing rates in situ, there should have been an impact by $\mathrm{N}$ addition also in these short-term laboratory experiments.

5 Bars and error bars show mean + standard error of four dates prior to the whole-lake nutrient manipulation (see methods in main paper for more information). 